\title{
Cattle diets in tall forb communities on moun- tain rangelands
}

\author{
M.H. RALPHS AND J.A. PFISTER
}

\begin{abstract}
Authors are range scientists, USDA, Agr. Res. Serv., Poisonous Plant Research Laboratory, 1150 East 1400 North, Logan, Ut. 84321.
\end{abstract}

\begin{abstract}
Thirteen grazing studies have recently documented diet botanical composition of cattle in tall forb plant communities on mountain rangelands. In forb-dominated plant communities, cattle selected forbs in proportion to their availability, ( 46 to $83 \%$ of their diets). In grass-dominated communities, forbs comprise only 11 to $32 \%$ of diets. On a landscape scale cattle preferred and spent proportionally more time grazing in forb-dominated communities. Taken together, these studies indicate that cattle have a wide acceptability for forage classes and can effectively utilize forbdominated high mountain rangelands.
\end{abstract}

Key Words: cattle grazing, forbs, tall forb plant community, diet selection

The generalized forage preferences of domestic livestock"cattle prefer grass, sheep prefer forbs, and goats prefer shrubs" (Stoddart et al. 1975)-are ingrained deeply in the range management profession. These relative preferences are the basis by which range suitability, carrying capacity, stocking rate, and management strategies are based. When livestock do not conform to these preferences, management decisions based upon this paradigm will be in error.

Much of the high mountain rangeland is thought to be better suited for sheep grazing, due to the rough topography and prevalence of forbs in the plant communities. But what if cattle would efficiently utilize the forbs on these high mountain allotments? Perhaps administratively dictated boundaries between sheep and cattle range might be reconsidered and use of the resource would be allowed by either livestock species.

The purpose of this paper is to illustrate that cattle can efficiently use forbs on mountain rangelands. We conducted several cattle grazing studies in tall forb plant communities in the mountain big sagebrush, aspen, and subalpine vegetation zones in conjunction with research on cattle poisoning from larkspur (Delphinium spp.). These studies also provided an opportunity to describe cattle diets in the tall forb community in 4 widely separated localities.

\section{Study Areas}

\section{Manti, Utah}

Seven grazing trials were conducted at the head of Six Mile Canyon, $24 \mathrm{~km}$ east of Manti in central Utah in the subalpine vegetation zone at an elevation of $3,200 \mathrm{~m}$. The study pastures included scattered patches of Englemann spruce (Picea engelmannii Parry ex Engelm) with 2 distinct vegetation types. The Ribes montigenun/Agropyron trachycaulum type consisted of open grass areas interspersed with dense currant (Ribes spp.) mottes. Dominant grasses were slender wheatgrass (Agropyron trachycaulum (Link) Malte), mountain brome (Bromus carinatus Hook. \& Arn.), and Letterman needlegrass (Stipa lettermanii Vasey).

Manuscript accepted 28 Jan. 1992.
Dominant forbs were Louisiana sagebrush (Artemisia ludoviciana Nutt.), common dandelion ( Taraxacum officinale Weber), western yarrow [Achillea lanulosa (Nutt) Piper], vetch (Vicia spp.), and Aster spp. The second type occurred on snowdrift sites and was dominated by dense concentrations of tall larkspur (Delphinium barbeyi L. Huth), with sparser quantities of mountain bluebell (Mertensia ciliata (James) G. Don), elderberry (Sambucus racemosa L), lupine (Lupinus spp.), saw groundsell (Senecio serra Hook), and meadow barley (Hordeum brachyantherum Nevski).

\section{Ruby, Montana}

Four grazing trials were conducted in the upper Ruby River valley $93 \mathrm{~km}$ south of Sheridan, Mont. at $2,600 \mathrm{~m}$. The habitat type was Artemisia tridentata/Festuca idahoensis with 2 phases. The first phase was a grassland site dominated by Idaho fescue (Festuca idahoensis Elmer) with silky lupine (Lupinus sericeus Pursh), sulfur, and whorled buckwheat (Eriogonum umbellatum Torr. and $E$. heracleoides Nutt.), common dandelion, and western yarrow. The second phase was characterized by deeper loamy soil and a higher proportion of forbs dominated by sticky geranium (Geranium viscosissimum Fisch. \& Mey) and slender cinquefoil (Potentilla gracilis Dougl.). Idaho fescue, Poa spp. and waxy larkspur (Delphinium glaucescens Wats.) were abundant in both phases.

\section{Oakley, Idaho}

One study was conducted on the South Hills of south-central Idaho, $32 \mathrm{~km}$ west of Oakley, Ida., at $2,500 \mathrm{~m}$. Habitat type was Artemisia vaseyana var spiciformis / Bromus carinatus. Vegetation was dominated by duncecap larkspur (D. occidentale S. Wats.), slender wheatgrass, and mountain brome.

\section{Yampa, Colorado}

A single study was conducted $15 \mathrm{~km}$ west of Yampa, Colo., at 3,000-m elevation. Habitat type was Populus tremuloides-Abies lasiocarpa/Symphoricarpos oreophilus/tall forb. This site was characterized by aspen with scattered subalpine fir overstory, snowberry dominated the shrub component, and tall forbs dominated by tall larkspur, Englemann aster (Aster engelmanii D.C. Eaton), saw groundsel (Senecio serra Hook), false hellebore (Veratrum californicum Durand), and cow parsnip (Heracleum lanatum Michx.) along with mountain brome and slender wheatgrass.

\section{Methods}

Experimental pastures were fenced with temporary electric fence and ranged in size from 2 to 12 ha. Pasture size, grazing period, diet sampling method, and number of cattle in each study are listed in Table 1. Only diets of control cattle, or cattle whose diets would not be affected by the specific treatments of the studies, are included in this paper.

Cattle diets were estimated by bite count, scan sample, or eso- 
Table 1. Description of the studies, diet sampling methods, and habitat types.

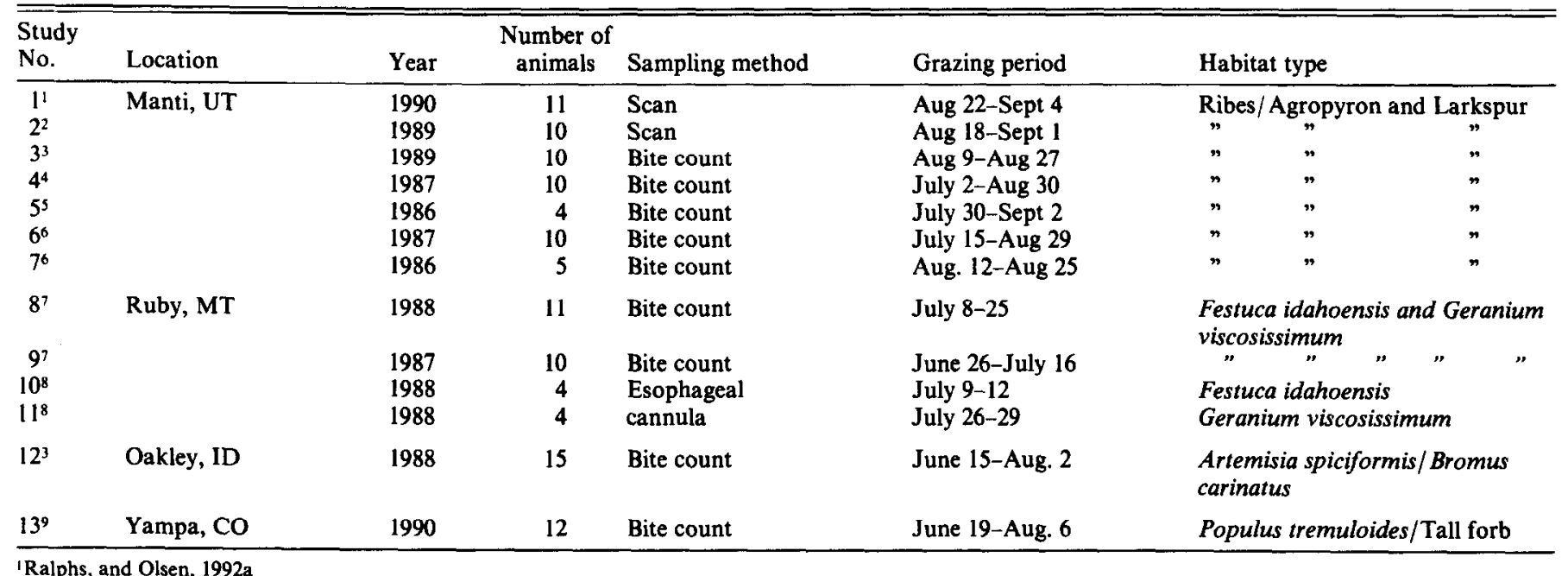

2Ralphs, and Olsen, 1992a

3Pfister and Manners 1991

4Pfister et al. $1988 \mathrm{~b}$

sPfister et al. $1988 \mathrm{a}$

${ }^{6}$ Lane et al. 1990

?Ralphs and Olsen $1992 \mathrm{~b}$

${ }^{8}$ Ralphs unpublished data

oPfister, unpublished data

phageal extrusa. Bite counts estimate the percent of each plant species in the diet (Lehner 1987). Each animal was observed for 5 to 20-min periods during each day, and the number of bites of each species was recorded. The observer rotated among all animals in the group from 1 to 3 times during each major grazing period of the day.

Scan samples estimate the proportion of time spent grazing particular species (Lehner 1987). A scan of all animals was made at 2-min intervals and the plant each animal was eating at that instant was recorded. Observations were made during all major grazing periods during the day.

Diet samples were collected from esophageal cannulated steers by removing the cannula and collecting extrusa in screen bottomed bags for 30 -min periods in the morning and evening grazing periods. Samples were frozen and freeze dried and plant fragments were identified and quantified by the microscope point technique (Harker et al. 1964).

The mean percentage of bites of each species, the proportion of time the species were grazed, or the percent of each species in the diet samples are presented with pooled standard errors.

At Manti and Ruby where more than 1 habitat type occurred in the pasture, each observation was coded with the site animals were grazing, and the proportion of time spent on each site and site preference were calculated. A preference ratio of 1.0 indicates that the site was grazed in proportion to its area. A ratio greater than 1.0 indicates site preference, while a ratio less than 1.0 indicates avoidance.

Standing crop of major forage classes was estimated at the beginning of each study by clipping 10 to 30 plots $(0.25-, 0.5$-or $1-\mathrm{m}$ plots depending on site) systematically located throughout the pastures.

\section{Results and Discussion}

Herbaceous standing crop ranged from 1,200 to $2,500 \mathrm{~kg} /$ ha (Table 2). Forbs comprised over $80 \%$ of the standing crop at all locations except Ruby, where forbs comprised $60 \%$ of the standing crop on the forb site and $40 \%$ on the grass site.

Forbs dominated cattle diets at Manti, ranging from 59 to $83 \%$

Table 2. Standing crop of forage classes.

\begin{tabular}{|c|c|c|c|c|c|c|}
\hline $\begin{array}{l}\text { Study } \\
\text { No. }\end{array}$ & Location & Year & Grass & Forb & Shrub & Total \\
\hline \multicolumn{7}{|c|}{ ( $\mathrm{kg} / \mathrm{ha} \pm$ standard error) } \\
\hline 1 & Manti & 1990 & 255 & 1049 & 52 & 1356 \\
\hline 3 & & 1989 & $246 \pm 62$ & $2297 \pm 335$ & 0 & 2543 \\
\hline 4 & & 1987 & $183 \pm 27$ & $1478 \pm 61$ & 0 & 1661 \\
\hline 5 & & 1986 & $232 \pm 48$ & $2190 \pm 440$ & 0 & 2422 \\
\hline 6 & & 1987 & 196 & 967 & 39 & 1202 \\
\hline 7 & & 1986 & 353 & 1095 & 0 & 1448 \\
\hline 8 & Ruby & 1988 & $799 \pm 85$ & $898 \pm 135$ & 0 & $1697 \pm 216$ \\
\hline 9 & Ruby & 1987 & 1381 & 762 & 0 & $2143 \pm 73$ \\
\hline 10 & Ruby grass & 1988 & $744 \pm 113$ & $472 \pm 112$ & 0 & $1216 \pm 103$ \\
\hline 11 & Ruby geranium & 1988 & $913 \pm 159$ & $1477 \pm 222$ & 0 & $2390 \pm 212$ \\
\hline 12 & Oakley & 1988 & $246 \pm 30$ & $1177 \pm 31$ & 0 & 1423 \\
\hline 13 & Yampa & 1990 & $439 \pm 55$ & $1562 \pm 219$ & & $2001 \pm 212$ \\
\hline
\end{tabular}


Table 3. Cattle diets in the tall forb plant community on mountain rangelands (\% of bites, $\%$ of time spent grazing species, or $\%$ of diets).

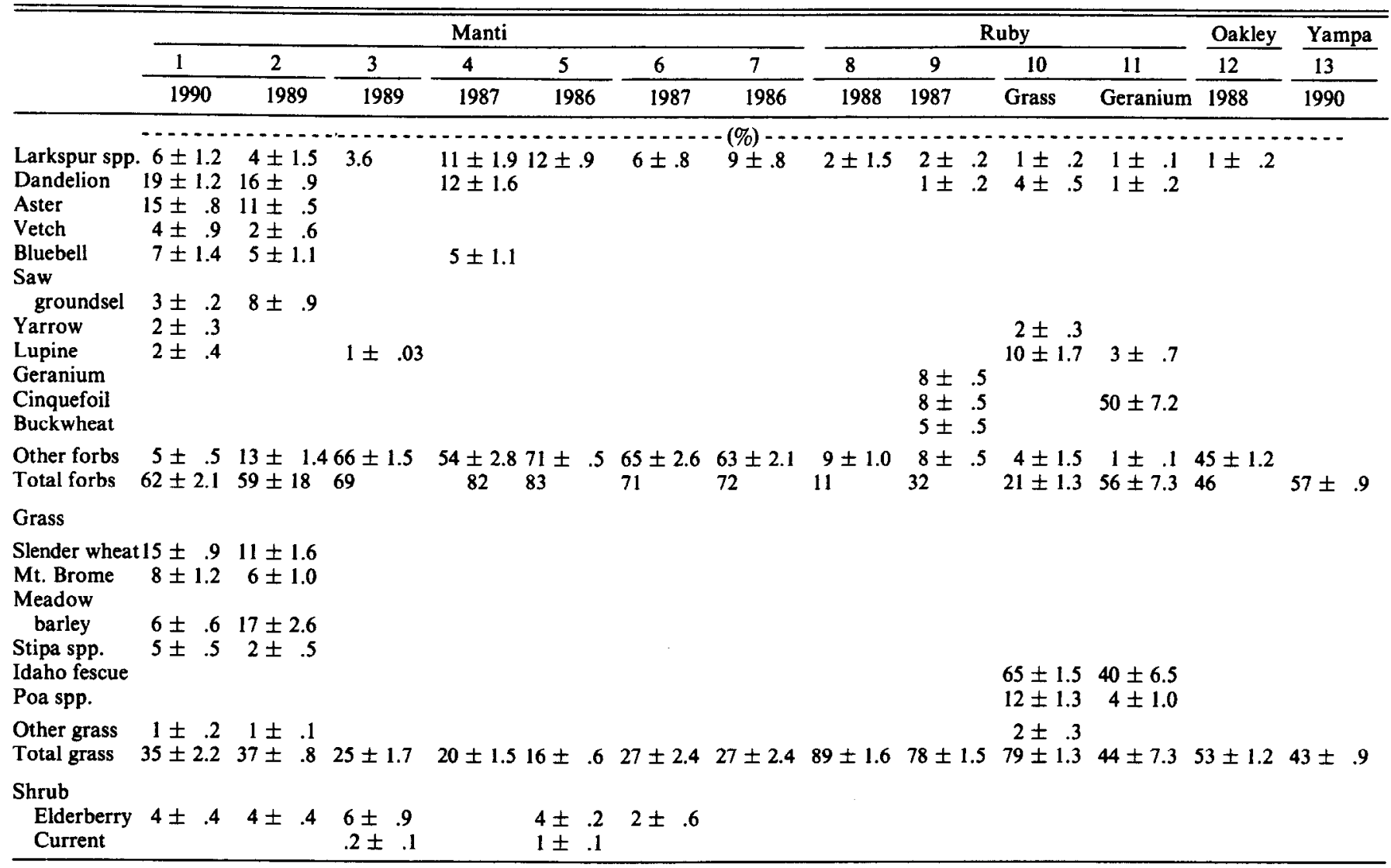

of the diets (Table 3). Dandelion and aster were highly preferred, and were most abundant in both the open grass and larkspur sites (Table 4). Bluebell was also highly preferred, but was restricted to the larkspur site and was relatively scarce. Saw goundsell and lupine were avidly selected later in the grazing season. Slender wheatgrass and mountain brome were dominant grasses on both sites and comprised most of the grass component in the diets.

Forbs varied in cattle diets at the Ruby site (Table 3). When cattle were confined to the tall forb site (study 11), forbs comprised $56 \%$ of diets and slender cinquefoil was the dominant forb in the diet. When cattle grazed the grass-dominated site (study 10 ), or the combination of sites (study 8 and 9), forbs comprised only 11 to $32 \%$ of diets. The grass standing crop on both of these sites was higher than at other locations (Table 2) and may account for the higher proportion of grass in the diet. Forbs comprised 46 and $57 \%$ of cattle diets at Oakley and Yampa, respectively.

At Manti and Ruby, where both grass and forb sites occurred in the study pastures, cattle preferred to graze in the forb sites.
Preference ratios for the forb site ranged from 1.1 to 1.4 (Table 4), compared to .52 to .95 for the grass sites.

Cook (1983) lamented the fact that many range managers still consider forbs as "weeds" or "least desirable" plants in managed plant communities. He argued that forbs may be dominant or sub-dominant life forms in the structure and function of climax plant communities. They are also readily eaten by both cattle and sheep, and provide a substantially higher level of nutrition (i.e., higher nitrogen and lower in fiber) than grasses.

Other studies have reported high levels of forbs in cattle diets on mountain rangelands. Thilenius et al. (1975) reported that forbs comprised $40 \%$ of cattle diets on subalpine range in the Big Horn Mountains in Wyoming, while contributing $84 \%$ to the herbage production. They concluded that forbs are more important as cattle forage on summer range than previously thought.

Willms et al. (1980) reported that cattle selected forbs for $42 \%$ of their diets although forbs comprised only $17 \%$ of the ground cover on Douglas fir/pinegrass range in British Columbia. Other studies

Table 4. Percent of time spent grazing in respective sites, the proportion of the pasture occupied by the site and the preference ratio.

\begin{tabular}{|c|c|c|c|c|c|c|c|c|c|c|}
\hline \multirow[b]{2}{*}{ Location } & \multirow[b]{2}{*}{ Year } & \multicolumn{3}{|c|}{ Forb } & \multicolumn{3}{|c|}{ Grass } & \multicolumn{3}{|l|}{ Shrub } \\
\hline & & Time & Area & Ratio & Time & Area & Ratio & Time & Area & Ratio \\
\hline Manti & $\begin{array}{l}1986 \\
1987 \\
1990\end{array}$ & $\begin{array}{l}39 \\
23 \\
49\end{array}$ & $\begin{array}{l}34 \\
19 \\
45\end{array}$ & $\begin{array}{l}1.15 \\
1.21 \\
1.10\end{array}$ & $\begin{array}{l}42 \\
60 \\
38\end{array}$ & $\begin{array}{l}64 \\
72 \\
40\end{array}$ & $\begin{array}{l}.65 \\
.83 \\
.95\end{array}$ & $\begin{array}{l}20 \\
17 \\
13\end{array}$ & $\begin{array}{r}3 \\
9 \\
15\end{array}$ & $\begin{array}{r}6.6 \\
1.88 \\
.86\end{array}$ \\
\hline Ruby & $\begin{array}{l}1987 \\
1988\end{array}$ & $\begin{array}{l}42 \\
75\end{array}$ & $\begin{array}{l}48 \\
48\end{array}$ & $\begin{array}{l}1.12 \\
1.44\end{array}$ & $\begin{array}{l}58 \\
25\end{array}$ & $\begin{array}{l}52 \\
52\end{array}$ & $\begin{array}{l}.87 \\
.52\end{array}$ & & & \\
\hline
\end{tabular}


reported that forbs contributed a high proportion to cattle diets in early summer but declined as the season progressed (Currie et al. 1977, Uresk and Paintner 1985). Holechek et al. (1982) concluded that cattle frequently diverge from traditional grass diets on mountain range.

\section{Management Implications}

This compilation of studies demonstrates that forbs dominated cattle diets in tall forb communities on high mountain rangeland. Cattle are opportunisitic grazers and will often select forbs at levels similar to or exceeding their proportion in the standing crop. Management decisions should not discount the use of forbs by cattle. Administrative barriers between sheep and cattle allotments should be relaxed to consider exchange of use, common use grazing, and exchange of allotments to make efficient use of the forage resource.

\section{Literature Cited}

Cook, C.W. 1983. "Forbs" need proper ecological recognition. Rangelands 5:217-220.

Currie, P.O., D.W. Reichert, J.C. Malechek, and O.C. Wallmo. 1977. Forage selection comparisons for mule deer and cattle under managed ponderosa pine. J. Range Manage. 30:352-356.

Haker, K.W., D.T. Torell, and G.M. VanDyne. 1964. Botanical examination of forage from esophageal fistulas in cattle. J. Anim. Sci. 23:465-469.

Holechek, J.L., M. Vavra, J. Skovlin, and W.C. Krueger. 1982. Cattle diets in the Blue Mountains of Oregon II. Forests. J. Range Manage. 35:239-242.

Lane, M.A., M.H. Ralphs, J.D. Olsen, F.D. Provenza, and J.A. Prister. 1990. Conditioned taste aversion: potential for reducing cattle loss to larkspur. J. Range Manage. 43:127-131.

Pfister, J.A., M.H. Ralphs, and G.D. Manners, 1988a. Cattle grazing tall larkspur on Utah rangeland. J. Range Manage. 41:118-122.

Pfister, J.A., G.D. Manners, M.H. Ralphs, Z.X. Hong, and M.A. Lane. 1988b. Effects of phenology, site and rumen fill on tall larkspur consumption by cattle. J. Range Manage. 41:509-514.

Pfister, J.A., and G.D. Manners. 1991. Mineral supplementation of cattle grazing larkspur-infested rangeland during drought. J. Range Manage. 44:105-111.

Ralphs, M.H., and J.D. Olsen. 1992a. Comparison of larkspur alkaloid extract and lithium chloride in maintaining cattle aversion to larkspur in the field. J. Anim. Sci. (in press).

Ralphs, M.H., and J.D. Olsen. 1992b. Prior grazing by sheep reduces waxy larkspur consumption by cattle: an observation. J. Range Manage. 45:136-139.

Stoddard, L.A., A.D. Smith, and T.W. Box. 1975. Range management. McGraw-Hill, N.Y. 3rd Ed. p. 257.

Thilenius, J.F., G.R. Brown, and C.C. Kaltenbach. 1975. Treating forbdominated subalpine range with 2,4-D: effects on herbage and cattle diets. J. Range Manage. 28:311-315.

Uresk, D.W., and W.W. Paintner. 1985. Cattle diets on a ponderosa pine forest in the northern Black Hills. J. Range Manage. 38:440-442.

Willms, W., A. McLean, R. Tucker, and R. Ritcey. 1980. Deer and cattle diets on summer range in British Columbia. J, Range Manage. 33:55-59.

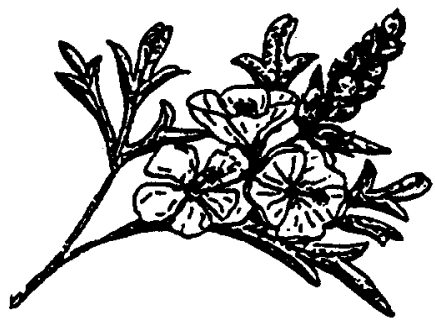

\section{Medicinal Wild Plants of the Prairie} An Ethnobotanical Guide

\author{
Kelly Kindscher \\ Drawings by William S. Whitney
}

"One of the most important, original contributions to American medicinal plant literature in decades. Combining thoughtful insight with thorough research, this book has broad appcal, yet is scientifically sound-a rare blend with lasting value."-Steven Foster, coauthor of A Field Guide to Medicinal Plants and editor of Botanical \& Herb Reviews.

336 pages. $\$ 25.00$ cloth, $\$ 9.95$ paper

\section{Also of interest}

Edible Wild Plants of the Prairie

An Ethnobotanical Guide

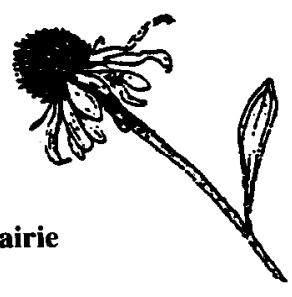

Kelly Kindscher

"A fascinating exploration of natural culinary delights."Sierra. 288 pages, illustrated. $\$ 25.00$ cloth, $\$ 9.95$ paper

\section{Flora of the Great Plains}

The Great Plains Flora Association

Updated! New ten-page supplement and more than 300 changes in the original text. Winner of the New York Botanical Garden's Gleason Award. 1,416 pages. $\$ 55.00$

\section{Roadside Wildflowers of the Southern Great Plains}

Craig C. Freeman and Eileen K. Schofield

Featuring 253 full-color photographs and organized by color and blooming season. "Visually pleasing, informative, scientifically accurate, and easy to use."-Brittonia. 288 pages, illustrated. $\$ 29.95$ cloth, $\$ 17.95$ paper

Available at bookstores or direct from the press. Visa and MasterCard accepted. (913) 864-4155

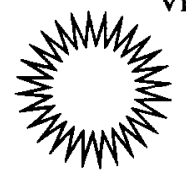

University Press of Kansas 2501 West 15th Street, Lawrence KS 66049 